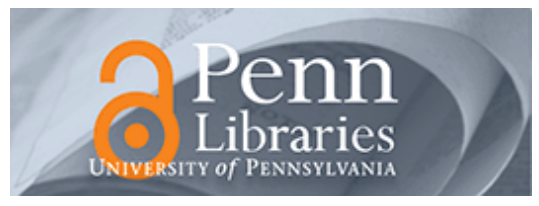

University of Pennsylvania ScholarlyCommons

$1-1-1997$

\title{
20 Years of Television in Israel: Are There Long-Run Effects on Values, Social Connectedness, and Cultural Practices?
}

Elihu Katz

University of Pennsylvania, ekatz@asc.upenn.edu

Follow this and additional works at: https://repository.upenn.edu/asc_papers

Part of the Communication Commons

\section{Recommended Citation}

Katz, E. (1997). 20 Years of Television in Israel: Are There Long-Run Effects on Values, Social Connectedness, and Cultural Practices?. Journal of Communication, 47 (2), 3-20. https://doi.org/10.1111/ j.1460-2466.1997.tb02703.x

This paper is posted at ScholarlyCommons. https://repository.upenn.edu/asc_papers/289

For more information, please contact repository@pobox.upenn.edu. 


\title{
20 Years of Television in Israel: Are There Long-Run Effects on Values, Social Connectedness, and Cultural Practices?
}

\author{
Abstract \\ Television broadcasting was introduced in Israel late, after years of debate over its likely effects. \\ Opponents of the medium, led by David Ben-Gurion, thought that renascent Hebrew culture would be \\ undermined by the introduction of foreign values, that the People of the Book would turn into the people \\ of television, that ascetic and pioneering values would be uprooted by consumerism, that ideological \\ politics would be displaced by personality politics. Those in favor of the introduction of television argued \\ that the medium carried no intrinsic message, that it would do whatever it was told inform, educate, teach \\ Hebrew, absorb immigrants, foster creativity, enfranchise marginal groups, show Israel's achievements to \\ itself and to the world. \\ Disciplines \\ Communication
}




\section{Twenty Years of Television in Israel: Are \\ There Long-Run Effects on Values and \\ Cultural Practices?}

Elihu Katz and Hadassah Haas

Television broadcasting was introduced in Israel late, after years of debate over its likely effects. Opponents of the medium, led by David Ben-Gurion, thought that renascent Hebrew culture would be undermined by the introduction of foreign values, that the People of the Book would turn into the people of television, that ascetic and pioneering values would be uprooted by consumerism, that ideological politics would be displaced by personality politics. Those in favor of the introduction of television argued that the medium carried no intrinsic message, that it would do whatever it was told inform, educate, teach Hebrew, absorb immigrants, foster creativity, enfranchise marginal groups, show Israel's achievements to itself and to the world.

The absence of television seemed more acute on the eve of the Six Day War of 1967 inasmuch as TV broadcasts were being received from the surrounding Arab states. Indeed, television was introduced in Israel shortly after this war-not only to right the ostensible propaganda disadvantage, but because it was thought, wishfully, that the new 
medium would make for effective communication between Israelis and people in the newly occupied territories. Some of those who opposed television thought that this was simply a bandy rationalization, but in the post-war euphoria, not many opponents were left.

In 1970-but without any specific reference to the fact that television broadcasting had just begun-the Ministry of Education and Culture commissioned a major study of the uses of leisure, culture and communication in Israel (Katz and Gurevitch, 1974). Twenty years later, in 1990, a repeat study was commissioned by the Ministry and the US-Israel Bi-National Science Foundation. Based on face-to-face interviews with national samples of 3000 Israelis (the 1990 study includes the Arab sector as well), the two studies are comparable in almost every respect. By good fortune, therefore, we are in a position to assess the long-run effects of introducing television on a whole society. This is much easier said than done, however, because so many other things have happened during the 20 years between the studies. It is only at great risk, therefore, that one can attribute causality to television in accounting for the changes in Israeli culture and society during this period. It is especially ironic, because not a few of the changes that emerge from comparing the two studies coincide with the predictions of its effect-more often with 
those of its opponents than with its proponents.

Thus, the trouble with trying to analyze the effects of 20 years of television is that this same 20 -year period also includes two wars, a doubling of the population, and an increase in the level of general education such that the society, on average, is three years more educated than in 1970. Moreover, 1977 saw the first overturn of Israeli politics from left to right and the coming to political maturity of the second generation of immigrants from Asian and African countries. The new parity between citizens of Eastern and Western background challenged not only the long-standing political consensus, but also the (predominantly Western) cultural order. During the 20-year period, an additional hour of leisure was added to the day, a second day off from work was given (Friday) and a rise in the standard of living achieved. To study the long-run effects of television, therefore, one has to know how to sort out the effects of television from those of war, affluence, education, political change, cultural pluralism and so on!

Having sounded the warning, let us proceed nevertheless to examine changing trends in the values and cultural practices of Jewish Israelis over these twenty years, and to speculate about the extent to which they may be attributable to television. ${ }^{1}$ To accomplish this, the paper will proceed as follows: (1) it will present an overview of the 
ways in which television broadcasting was institutionalized in Israel;

(2) it will consider the patterns of television viewing; (3) it will report on major changes in the patterns of consuming culture and the arts, including reading; (4) it will review the study's findings concerning value changes in Israeli society during this period; (5) it will report on the changes in the functions and gratifications provided by the media, old and new, with respect to these values. Having done so, we shall return to weigh the possible long-run effects of television.

\section{Television: The Israeli Version}

From its inception, broadcasting in Israel was a monopoly service provided at first by the Government, and, from 1965, by a BBC-like authority financed by a license fee and directed by a Board of Governors representing the political spectrum but independent of Government. When television was established in 1968, joining radio as one of the services of the monopolistic Israel Broadcasting Authority (IB), Israel Television operated only one channel-which it yielded during the daytime hours to the Educational Broadcasting service of the Ministry of Education. Cable television by subscription was introduced in the early 90s, and a second over-the-air channel (like the British ITV) was introduced in 1993, financed by advertising 
but overseen by a public Board, different from that of the IBA.

Before the very recent introduction of multiple channels, Israel TV had excelled in coverage of news and public affairs, although this achievement was sometimes impeded by the overly politicized appointments of the Governing Board and of the Director General. As good as it was at public affairs, it was poor, at best, in original drama and light entertainment. Jokers used to say that Israel television could well do without drama and entertainment, since there is plenty of that in the news.

In its best days, the main 9 pm news attracted $70 \%$ of the population on an average evening. Critics and advocates of multiple channels objected that a society cannot claim to be democratic if it has only one television channel and one major news bulletin. Yet, the evidence shows that this highly politicized society collected itself for the nightly news magazine and willingly accepted its agenda for political discussion. There was no evidence of brainwashing: hawks and doves, Jews and Arabs viewed the monopolistic news magazine, believed it on the whole, and used it to talk politics not only in like-thinking groups but across political divisions. ${ }^{2}$ Indeed, the $9 \mathrm{pm}$ news magazine became a sort of civic ritual during which the society communed with itself. There was an informal norm that attendance was "required," and that there were to be no intrusions during the 
news-no telephone calls, for example. American politicians now are talking wishfully about how to organize "electronic town meetings" -having blithely exchanged their three channels for hundreds. Rather than undemocratic, the lesson of 15 years of Israel TV is that participatory democracy may be enhanced, rather than impeded, by gathering its citizens in a single public space set aside for receiving and discussing reliable reports on the issues of the day.

The introduction of multiple channels has changed the picture. The heavy emphasis on news and public affairs has given way to much lighter entertainment on the new channels. Even the many cheap-to produce political talk shows are sprinkled with very high doses of sensation, scandal, personalities, provocations, and pop. And advertising interrupts everything. Ironically, the introduction of a competing news magazine (at the same hour as the original) has lowered the total number of viewers of both programs-as if the very offer of choice abolished the norm of collective viewing of the television news.

Like in other countries-not only the smaller ones-a high percentage of television programming is imported from abroad, especially from the United States. The new second channel promised to commission many more programs from local producers, but with double the hours of broadcasting, the overall ratio of domestic to 
imported programming has declined, if anything, to well below 50\%. If one also takes account of the dozen or more cable channels-now reaching some $60 \%$ of the population-the proportion of homemade programming is tiny.

The idea that fewer hours of broadcasting might result in better programs does not occur to anybody. Since its inception in 1968, Israel TV has gone from three nights per week of experimental broadcasting, to six nights per week, and, after a religious/political/ cultural battle over Sabbath-eve broadcasting, to seven nights. The next frontier was breakfast television. And with the inauguration of cable channels and the second over-the-air channel, television in Israel has become the non-stop public utility so familiar in the rest of the world.

\section{The Viewers}

Apart from a few religious and secular ascetics, every home (94\%) has a television set, and the modal viewing time is 2-3 hours. More telling, perhaps, is that one third of the leisure time of adult Israelis is spent viewing television. There are five hours unspoken for on working days, of which an average of 1.7 hours go to viewing TV, and of the combined 14.1 hours of leisure on the two days of the weekend, 4.3 hours go to $\mathrm{TV}^{3}$ Compared to 1970 , the added hours of 
leisure come from a shorter workday and a longer weekend, in addition to the reduced time spent on housework, averaging over an hour a day. In a large sense, television may be said to be consuming all of the extra leisure time made available since 1970 without major harm to other activities. Surprisingly, it has not even reduced time spent outside the home. Nevertheless, in close-up, one should note the decline in time spent sleeping, eating, reading newspapers and books, and listening to the radio. Time spent on each of these activities has been reduced since 1970, although only by minutes, not hours, per day.

Men watch more hours of TV than women. Older people and the less educated are heavier viewers.

When the first channel was just being launched in 1970, Israelis ranked their preferences among television offerings as information first, entertainment second, and culture third. Fifty five per cent put information in first place. In 1990, information and entertainment were ranked first by a smaller proportion of viewers (43\%), tied for first place with entertainment (43\%). That does not mean that they wish the quality of programming to be lower: other data suggest, rather, that they are asking for more variety. They also want more "familiar" programs those that are home-produced--even while criticizing the news for being too domestic and not worldly 
enough.

It is very difficult to answer the question whether television has increased or decreased attention to civic affairs. Israel is considered to be a country of avid news consumers, and during the years of monopolistic national broadcasting the most highly rated program on television by far was the evening news. Radio news bulletins and magazines were, and still are, highly attended. Yet, comparing 1990 with 1970, we note some decline in viewer preference for news over other genres, and a substantial decline in the total audience for TV news (especially since the introduction of competing channels). The level of newspaper reading remains very high (some $90 \%$ read a daily newspaper), but the habit of reading two newspapers has given way to reading only one especially since the major evening tabloids are distributed, in effect, at the same hour as the morning papers. Also the number of newspapers has declined.

Is television responsible for any of this? Perhaps so. It may be argued that in its first years, television presented itself as the national showcase for news, reduced attention somewhat to the other news media, and gradually redirected audience attention elsewhere, to what Postman (1986) would call amusement. But, like others of the ostensible long-run effects of television, this is no more than an interpretation, a surmise; it may well be that the sources of change 
originate elsewhere and that changes in television viewing habits is more an effect than a cause.

\section{Cultural Practices, 1970-1990}

Has television affected other forms of consuming culture? What about the arts?

It is important to recall at this point that the amount of time spent outside the home-except for the aged-remains virtually unchanged between 1970 and 1990, and therefore unaffected by television. Enough extra leisure is available for people to include 2-3 hours per day of TV viewing in their time budgets ${ }^{4}$ without sacrificing some 2112 hours "outside"- visiting, meandering, going to meetings, and consuming culture.

What has changed during these 20 years is what people do when they go out. Compared to 1970, there has been a major decline in the consumption of the arts. There is a per capita drop in the scope and/or frequency of attendance at cinema, theatre, concerts, museums, and lectures. This is very surprising since we had reason to expect an increase in participation in the arts inasmuch as the society is three years more educated since 1970, and education is positively correlated with consumption of the arts. 
Ironically, the box-offices are unaware that there has been a decline in per capita consumption of the arts. The reason they don't notice is because the population has doubled, so that in 1990 the theater and concert halls are as full as they were in 1970! Only we, the researchers, know that a sea-change is in progress! Employing a variety of measures it can be shown that the scope of the audience, or frequency of attendance, or both, have lowered the extent of involvement in the institutions of "high" culture. Nobody is surprised that cinema attendance is down- casually putting the blame on television-but the same drop applies to theater, concerts, museums, etc.

Before making the wrong interpretation, however, it should be added that attendance at sporting events is also down. In 1990, per capita attendance at such events is lower than it was in 1970-both in scope and in frequency.

By contrast, there has been a rise, between 1970 and 1990, in the rate of going to pubs, eating out in restaurants, domestic and foreign travel, and participatory sports.

Our reading of these findings suggests that there is a decline in what may be called spectacle and a rise in those activities that are active, interactive, intimate, where participants bring their own programs along. In other words, there is a decline in those things 
which require one to sit in a particular place at a particular time, to watch a curtain go up and listen to some professional performer deliver a message from the stage. Correspondingly, leisure pursuits that have to do with activity, interactivity, flexible time, one's own small group and one's own agenda are on the rise.

Let us consider whether television may be to "blame." Television might explain these changes in the sense that it has given us an overdose of spectacle. People are fed up with staring; there's enough spectacle in the living-room, and when one goes outside the home one looks for something different. When people do go out they want to do more than stare. They want to be active, interactive, intimate, creative, and so on.

Any explanation, of course, would have to account for the decline in reading as well. Clearly, reading is not a spectacle. Nor does television displace the functions of reading, as we shall see. But reading does involve a lot of looking, and so perhaps the explanation does apply-at least until we find a better one.

Another possibility is that television satiates the appetite for the arts and the other media. We would all intuitively agree that cinema attendance has been hurt by television. The fact is, however, that people are seeing more, not fewer, films than they did in 1970, but they are seeing them on TV. This may be equally true for theater, 
concerts, sports, even museums, as well as reading fiction and reading news. The arts, especially cinema, are the content of television. According to McLuhan's (1964) rule, each new medium incorporates its predecessor as content. Perhaps television gratifies these needs for experience of the arts.

One must also take account of the alleged decline of the performing arts in other countries, too. ${ }^{5}$ Of course, television may be the cause here as well, but a competing explanation would suggest that the culture of pluralism and postmodernism has challenged the Western canon and shaken up the entrenched hierarchy of "high" and "popular" art. It may be that people--even the upwardly mobile--don't "have to" prefer Beethoven to rock any more. We have already noted the coming of age of the second generation of Israelis whose parents originate from Africa and Asia, and the highest drop in arts participation is among the Israeli-born of 20-30 years, not only among those of Eastern origin but among those of Western parentage as well. The fact that the decline is no less strong among the Western groups born to television rekindles the possibility that television may be a cause.

What we are suggesting is that television may have preempted the other performing arts by doing what they do, as well as fostering an awareness that the rest of society is doing the same thing at the 
same time. In this sense, television offered the "togetherness" of a spectacle, superceding the spectacle of going to the theater, a concert, or to a political rally to share an experience with others who are present. Is it possible, we are asking, that the collective experience of viewing television-- of viewing one-channel, public television-has satiated not only the desire for spectacle but the further need for widely shared experience and deliberation? Rather than contributing to the atomization of society and undermining its culture, as the opponents feared, Israel Television may have moved the collectivity from outside to inside, but served the collectivity very well, nevertheless. Stated otherwise, we are speculating on the possibility that 20 years of monopolistic public television offered Israelis a strong new taste of collectivity in the double sense of simultaneous communion with very large numbers of one's compatriots, and shared content of collective import. Cardiff and Scannell (1987) make much the same case for the early days of both $\mathrm{BBC}$ radio and $\mathrm{BBC}$ television. Dialectically, we further propose that this "togetherness" and its implicit obligations became tiresome and oppressive after a while (as did other aspects of collective culture) and pushed people to find groups of intimates with whom to do "other" kinds of things. 


\section{Value Changes, 1970-1990}

Another area in which we have observed change between 1970 and 1990 is the area of values, and these changes also reverberate with some of the concerns of the opponents of television. But almost nobody would venture that television is powerful enough, in itself, to have induced change in such deep-seated values. It is more reasonable that the impetus for change comes from elsewhere, and that the institutionalization of television and the viewing habits that it cultivates are only part of a larger picture. Let us now examine these changes, paying particular attention to values such as individualism versus collectivism and hedonism versus asceticism, that have entered our discussion so far.

At the outset, it should be emphasized that the society is very traditional on the whole. Compared to other western-oriented societies, family, nation and collectivity are very important, as is connection with the religious tradition. National and traditional holidays involve almost everyone, whether in religious or secular guise. Escapism is very low. But changes are taking place, slowly but surely.

We asked a series of value questions in this national survey about the "importance" Israelis attribute (1) to self, (2) to family, (3) to friends, (4) to state and (5) to peoplehood. Questions touched on 
affective and cognitive aspects in each of these realms. We asked, for example: How important is it for you to know yourself, to want to study, to make your day an orderly one, to feel that you are using your time well, to strive for a higher living standard, to escape from everyday reality, to overcome loneliness, and so on. This is the domain of self-concern. For the primary group area, we asked about the importance, cognitively and emotionally, of spending time with family and friends. With respect to state and people, we asked how important is it to you to understand what's going on in the world? How important is it to you to understand the true character of our political leaders? How important is it to you to believe in our leaders, feel pride in our state, and so on.

Many of the changes are small but consistent and significant; a few are very sharp. Table I displays these changes over time. Overall, there is an increase in concern for self and a decreased concern for society and state. There is more egoism than there was 20 years ago. Although concern for the future is still predominant, concern for the present has risen sharply. Pleasure is more highly valued, and there is an increase in the valuation of leisure as compared with work. Indeed, the importance of leisure is now more or less equivalent to the importance of work, whereas in 1970 work was more important than leisure, future was far more important than present. In sum, there is a. 
Table 1

The Importance of Needs-1990 and 1970 (Percent citing the need as "very important")

$\begin{array}{ll}1990 & 1970 \\ (N=1450) & (N=196\end{array}$

\section{Self identity}

1. Cognitive needs (A1, B1)

1. To develop good taste $\quad 66 \quad 61$

* 2. To know myself $\quad 74 \quad 66$

* 3. To want to study $\quad 65 \quad 56$

4. To organize my day $\quad 69 \quad 63$

5. To feel I am making good use of my time $\quad 76 \quad 72$

6. To strive for a higher standard of living $\quad 57$

* 7. To obtain practical information for daily life $\quad 70 \quad 47$

2. Affective needs (A2, B1)

* 8. To be entertained $\quad 68 \quad 54$

9. To experience beauty $64 \quad 64$

10. To re-experience past events $\quad 35 \quad 32$

$\begin{array}{lll}\text { 11. To raise my morale } & 83 & 77\end{array}$

3. Affective-escapist needs

* 12 To overcome loneliness when I am alone at home $56 \quad 37$

* 13. To release tension $\quad 74 \quad 61$

14. To escape from the reality of everyday life $\quad 22 \quad 16$

15. To relive the experiences of other people $\quad 17 \quad 20$

Family

4. Affective needs (A2, B2)

16. To spend time with family $\quad 89 \quad 85$

Friends

5. Cognitive needs (A1, B3)

17. To learn how to behave among others $\quad 54$

18. To participate in discussions with my friends $\quad 66 \quad 63$

19. To feel that others think as I do 34

20. To feel that I am influential $\quad 48 \quad 47$

6. Affective needs (A2, B3)

* 21. To spend time with friends $\quad 68 \quad 55$

State

7. Cognitive needs (A1, B4)

22. To understand what goes on in Israel and in the world 82

23. To get to know the true qualities of our leaders $47 \quad 50$

24. To follow the way government performs its functions $58 \quad 60$

25. To know what the world thinks about us $\quad 67 \quad 70$

26. To understand those who disagree with $46 \quad 41$

government's policy

27. To understand how the Arabs feel $31 \quad 33$

8. Affective needs (A2, B4)

* 28. To have confidence in our leaders $\quad 63 \quad 77$

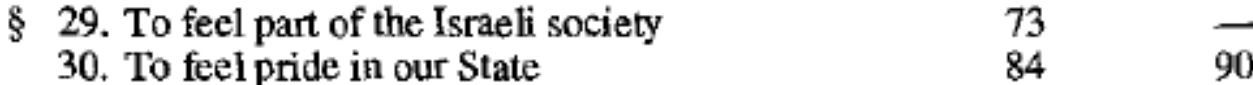

8 31. To feel close to the Israel Defense Forces (Zahal) 80 
* 32. To feel that I am participating in current events

\section{People}

9. Affective needs (A2, B5)

* 33. To feel in a festive mood

34. To get closer to the Jewish tradition

\& 35. To feel part of the Jewish people

\$ Question not asked in 1970.

* Values that have changed significantly ( $7 \%$ or more) between 1970 and 1990

rise in what might be called hedonism and individualism, and in the legitimacy of concern with self. These are big words for small changes, but they are very clear in the data

Their counterpart-the decline in collectivity-oriented values-may be observed in the lesser importance attributed to feelings of belonging to the larger society in matters such as the values of "having confidence in our leaders," "feeling that I am participating in current affairs," and "having pride in our state," although the latter is still at the top of the list. Organizational and political membership has experienced a decline. While the family retains its high place at both time periods, and is highly correlated with orientation to the collectivity, the value of spending time with friends has taken a major leap, and we know, from our study, that friends pull towards pleasure and pluralism and away from the burdens of the collectivity (Katz, Trope, and Haas, 1984). There is also a large increase in concern with "overcoming loneliness when I am alone at home."

Just as we asked in the case of changing cultural practices, we 
asked again in the case of changing values: does television have any share in these changes? Is television to "blame" in any way for the slow invasion of individualism and hedonism? It seems a fair guess that the answer is no. No one can deny that in its twenty years of existence as the sole national channel, Israel TV has demonstrated an incredible ability to seat the society together every night, to celebrate national achievements and religious occasions, indeed, to symbolize "togetherness."

In fact, if television has had any influence on values, we propose that it may have slowed these new trends. Rather than promoting individualism, pluralism or hedonism, it is more likely to have held them back, while reinforcing the sense of belonging to the civic sphere and the nostalgia for collectivity that permeates movements of national liberation such as Zionism. It is true that the opponents of television forecast a rise in self-oriented concerns and a decline in collectivistic ones: that the personal will supplant the collective, that egoism will displace altruism, that pleasure will uproot dedication. The only trouble with the prediction is that it does not at all correspond to the message of the first twenty years of Israel television, or to the shared experience it offered. 


\section{Function of Television and the Other Media}

To this point, we have acted as observers comparing changes in culture and values with what we know about the institutionalization of Israel TV, its organizational form, content and function. We wish to turn now to ask the viewers what they think are the functions of television and the other media. Do they see things as the researchers do?

To do so, we asked respondents to assess the helpfulness of each of five media-radio, television, book, newspaper, cinema-for satisfying each of the "values" outlined in the previous section (and in Table 1). For example, following the value question, "How important is it for you to understand what's going on in the world?" we asked further, "How useful are newspapers for this purpose? How useful are books for this purpose?" and so on for the five media. We are really asking which media best satisfy each of the respondents' needs or values. $^{6}$

In 1970, the newspaper was the predominant medium. Of the 35 concerns or values about which we inquired, the newspaper fulfilled more different functions than the other four. In 1990, television had displaced the newspaper very clearly as the medium which best fulfills more different kinds of concerns. ${ }^{7}$ 
That television has displaced the newspaper as the most diversified medium is not so surprising. The important point is that it ranks ahead of the other media in the area of the collectivity, especially in the emotional aspect of attachment to nation and people. More surprising, perhaps, is that television is rated the medium most helpful in satisfying national values that are not only affective but cognitive, i.e. not only "to feel pride in our state" but "to understand the true character of our leaders".

Table 2

Grading of Media for Satisfying Needs of Population (1990)

\section{Type of Needs}

\section{Self identity}

1. Cognitive needs

2. Affective needs

3. Escapist needs

Television

Cinema*

Book
Newspaper Television* Television
Book

Book

Radio
Radio

Radio

Cinema

Radio

Newspaper

Book

\section{Family}

Friends

5. Cognitive needs

Television Cinema

Book

Radio

Newspaper

Cinema

6. Affective needs Cinema

Television Radio

Book

\section{State}

7. Cognitive needs Newspaper* Television* Radio

Book

Cinema

8. Affective needs

Television Newspaper Radio

Book

Cinema

\section{People}

9. Affective needs Television Radio Book Newspaper Cinema 
After its widespread diffusion in the early '70s, television also became important in satisfying many other functions as well, such as overcoming loneliness and spending time with family. But in the minds of most Israelis, television takes only second place to books or cinema or both with respect to personal values such as knowing oneself, cultivating good taste, being entertained, aesthetic experience, spending time with friends, improving morale. In short, Israelis appear to be saying that television has outdistanced the other media-especially newspapers- in cognitive and affective aspects of relating to the collectivity even more than to the self or to interpersonal relations

The book, for its part, has retained all of its functions and even increased slightly in the number of important concerns it is thought to serve. Although the frequency of reading (not the overall percentage of readers) has declined somewhat, the book is holding its own from a functional point of view. Substantively, we can say that the book best fulfills functions related to self, especially affective ones. It is supreme among the five media in these functions. In Victor Nell's terms, "it is the affective part of self which the book best serves." Along with books, cinema continues to share the self-oriented and affective realm, that is, the emotional aspects of self-fulfillment. Cinema has become altogether different from television, functionally 
speaking, over the period of 20 years. If in 1970 cinema was considered the universal medium of entertainment, by 1990 it has become an art and behaves like the other arts, in the sense of being correlated with education: the higher the education the higher the consumption of cinema, and of theater, concerts, museums and galleries. This was not true for cinema prior to the inception of television.

The cinema and television do not fulfill each other's functions any more. What we now have is a cinema that is allied with books on the one hand, and television which is allied with radio. This may be truer in Israel than elsewhere, since news and public affairs dominate the broadcasting media, and the populace is highly politicized. It also explains the displacement by television of the functions of the newspaper. In 1970, people apparently thought that TV would join film as a medium of fiction and pleasure, but this expectation has not so far been fulfilled. Instead, TV joined newspapers and radio as a medium of current affairs. Yet the picture may reverse again as television channels multiply, and TV may yet rejoin cinema as a medium of pleasure.

In a word, after 20 years of Israel television, Israelis see it as it saw itself, namely, as a medium of the collectivity. More important than self-gratification, Israelis experienced their one-channel 
television as a way to connect with the larger society and its civic concerns. Escapism and entertainment are thought to have been better served by other media.

\section{Conclusion}

In comparing Israel of 1970 with Israel of 1990-prior to the diversification of channels now replacing the 20-year old monopoly-we have documented three areas of change: (1) The content of values has moved, however slowly, in an individualistic direction, in the direction of pleasure at the expense of civic obligation. (2) There is a decline in participation in the perforrnative arts, and in events that transpire at fixed times and places, with large numbers of participants. By contrast, there is a rise in activities that involve small groups of people doing their own things, at times and places of their own choosing. (3) The perceived division of labor among the media suggests that Israeli Jews identify their public television (prior to the new competition) as having served collective functions rather better (although not more frequently) than individualistic or hedonistic functions.

Simply stated, the data suggest that Israeli society-its values, its cultural practices-is moving slowly away from the collectivism that 
characterized it (and still does, relative to other societies) and towards greater self-indulgence. But Israel television cultivates collectivismas its viewers and observers both think. If so, and if television can affect basic values at all, we must infer that the process of value change has been slowed by television. As critical school theorists used to say, non-change or slowed change may be the major effect of the media of mass communication (Katz, 1980).

Nor can television be held directly responsible for the decline in the patterns of collective consumption of culture and the arts. The most compelling argument we can find to connect the two is that individualistic and interactive patterns of "going out" are, ironically, a reaction against the collectivism of staying home with television. ${ }^{8}$ In the simplest sense, if Israel television has successfully transformed the home into a theater or forum, then people want to do something else when they go out. In a larger sense, however, it suggests a saturation not only with the togetherness of Israel television but with togetherness and sacrifice made by the state and society during the first four decades of its embattled history. As in the case of values, Israel television is pulling against the stress of change, rather than with it.

Yet there is a nagging sense in which this may not be true. The message of television may be collectivistic, and its symbolic function 
likewise, as rightly perceived by its viewers. But there is also the reality of the medium as technology, and the way in which it situates its audience. While it may not keep them from going out, the fact is that its offerings can only be consumed at home. People may talk about the programs the next morning (30\% do), but is this the equivalent of going out to a meeting of one's trade union, or political party, or going out to the theater? Whether television has made home-and-family into a locus of political action and cultural experience is still an open question. It is equally possible that it has done no more than give people the illusion of being "engaged," in line with what Lazarsfeld and Merton (1948) call the "narcotizing dysfunction" of broadcast news, or what Gerbner et al. (1979) think of as pulling people out of society and into the isolation of their living rooms.

And one wonders, similarly, whether television as a medium has not had a major share in the personalization of politics that is now sweeping the country. Primary elections have displaced the power of the party chiefs in selecting candidates for the parliament, and a populist law has been passed calling for the direct election of the prime minister, to the consternation of most social scientists. There is good reason to believe that television has weakened the party system by moving it indoors and, willy nilly, making it intimate. 
Thus, early opposition to the introduction of television in Israel may have (1) been right, but for the wrong reasons, and (2) been right, but prematurely. Being right for the wrong reasons, the opponents suspected that television harbored a subversive message, not so much realizing that it was the medium itself rather than the message that may be problematic. Being right but prematurely, they could not have anticipated that the function of national integration would be so well served by Israel Television during its first two decades. But they may be right from now on. In the era of commercial, multi-channel narrowcasting, Israel may now have to make way for the escapist self-indulgence prematurely anticipated by the early opponents and latter-day critics like Houston and Postman.

Perhaps even more important than the message or the medium, the influence of television may be related to the form of its institutionalization in a particular society. The manifest and latent effects of a monopoly channel, operated by an independent Authority, in a newly democratic society, with a strong collective will, may be altogether different from the competitive, mixed commercial/public, multi-channel system now beginning to broadcast to a much more individualistic society of Israelis.

To summarize: (1) In spite of a persistent collectivism, we perceive a slow but sure trend towards self-gratification among 
Israelis at the expense of some decline in the pioneering values that characterized the society twenty and more years ago. (2) We perceive a decline in collective forms of out-of-home leisure in favor of more differentiated and pleasure-oriented pursuits typically enjoyed with small groups of friends. (3) Since its establishment 20 years ago, over one-third of leisure time in Israel is spent viewing television and some (but by no means all) of the functions of other media have been subsumed by television. (4) The safest thing to say about the long-run effects of television on the changes in Israel culture and society is that it is an impossible question to answer. (5) If one has to choose-on the basis of these comparative data-whether Israel television gave more support to the individualizing trend or to the norm of collectivism, there is a much stronger case to be made for the latter. The collectivism we have in mind has to do with shared and simultaneous pursuits, governed by norms of self-sacrifice and mutual obligation, performed in the knowledge that everybody else is similarly occupied; the Jewish Sabbath would be a classic example. (6) If Israel television did indeed serve as a bulwark against individualistic and hedonistic trends, it did so because of its message (offering a shared agenda to the society), because of the technology of electronic simultaneity and because of its independent-but-monopolistic form of organization. (7) At a deeper level, however, some of the latent aspects of the message 
(patriotism, perpetual tension, etc.) and of the medium (the atomistic way in which it situates viewers, its mode of personalization of issues) may also have pulled in the other direction. (8) There is good reason to expect that the new multi-channel television with its emphasis on choice and consumerism will give much stronger support to individuating trends it situates viewers, its mode of personalization of issues) may also have pulled in the other direction. (8) There is good reason to expect that the new multi-channel television with its emphasis on choice and consumerism will give much stronger support to individuating trends.

To repeat, the closest parallel to the argument of this paper about the first 20 years of television in Israel is Cardiff and Scannell's (1987) analysis of the national integration which was fostered during the early days of $\mathrm{BBC}$ radio and then $\mathrm{BBC}$ television.*

\section{Notes}

1. While the 1990 study included both Jews and Arabs, the 1970 study interviewed only Israeli Jews and therefore this comparison is limited to the Jewish population.

2. To repeat, Israeli Arabs are not included in this comparative study because the 1970 study did not encompass the Arab sector. It is noteworthy, however. 
That Israel Television is the primary and most reliable television news source mentioned by Israeli Arabs in 1990. We make no attempt here, however, to analyze the functions of television for the Arab sector.

3. These data are from "time budget" analysis where the interviewee is aided in reconstructing how he/she spent the past 24 hours. Averaging an activity such as TV viewing in this way includes the 0 hours of those who did not view at all "yesterday." Hence the discrepancy between the 2-3 hours of the modal viewer and the slightly lower figures (1.7 on weekdays, 2.3 on Fridays, 2.0 on Saturdays) noted here. Each fraction of an hour equals 6 minutes; thus 1.7 equals 102 minutes.

4 TV viewing averaged one hour in 1970 when many people were still without sets of their own, and the number of broadcast hours was small.

5. We have roughly comparable data from several European countries and the U.S. However, no systematic analysis has yet been undertaken across cultures.

6. Questions about the utility of the media were asked only with respect to those values considered at least "somewhat important" by the respondent, and with respect to those media to which the respondent was exposed at least to some extent. Thus, a respondent who attributed "no importance at all" to the need "to experience beauty" was not asked which media helped gratify this need. If he/she never goes out to see a film, questions about the helpfulness of cinema were not asked. 
7. The discussion that follows is based on changes in the roles of the five media with respect to each of the 35 different needs or values. Table 2 groups these needs into 9 categories, and averages them.

8. That does not mean that the higher standard of living and self--indulgence is not to be found in Israeli homes. Our argument, rather, is that the home is home to television, and that television is experienced as "we."

*Some of Meyrowitz (1985) also has bearing.

\section{References}

Cardiff, David and Paddy Scannell (1987). "Broadcasting and National Unity." In James Curran, Anthony Smith and Pauline Wingate, eds., Impacts and influences. London: Methuen.

Gerbner, George, Larry Gross, et al. (1979). "The demonstration of power." Journal of Communication 29: 177-196.

Houston, Beverle (1994). "Viewing television: The metapsychology of endless consumption." In Nick Browne, ed., American Television: New directions in history and theory. Chur, Switzerland: Harwood.

Katz, Elihu (1980), "On conceptualizing media effects," In Thelma MacCormack, ed., Studies in Communication, Vol. L Greenwich, CT: JAI Press.

Katz, Elihu and Michael Gurevitch (1974). The Secularization of Leisure. 
London Faber and Faber

Katz, Elihu and Michael Gurevitch (1976). The Secularization of Leisure:

Culture and communication in Israel. London: Faber and Faber;

Cambridge, MA: Harvard University Press.

Katz, Elihu, Ya'acov Trope and Hadassah Haas (1984), "Primary groups, mass communication and integration in armed forces and nation." In Erik Cohen, Moshe Lissak and Uri Almagor, eds., Tradition and Modernity: Essays in honor of S. N. Eisenstadt. Boulder, CO: Westview Press. Lazarsfeld, Paul F. and Robert K Merton (1948). "Mass communication, popular taste and organized social action." In Lyman Bryson, ed., The Communication of Ideas. New York: Harper.

McLuhan, Marshall (1964). Understanding Media: Extensions of man. New York: McGraw-Hill.

Meyrowitz, Joshua (1985). No Sense of Place. New York: Oxford University Press.

Postman, Neil (1986). Amusing Ourselves to Death: Public discourse in the age of television. New York: Viking. 